\title{
Frond dynamics of the commercial seaweed Gelidium sesquipedale: effects of size and of frond history
}

\author{
Rui Santos* \\ Laboratório Nacional de Engenharia e Tecnologia Industrial, Departamento de Estudos de Impacte Industrial, \\ Estrada do Paço do Lumiar, Azinhaga dos Lameiros, P-1600 Lisboa, Portugal
}

\begin{abstract}
Gelidium sesquipedale (Clem.) Born. et Thur is commercially exploited along the northeast Atlantic for the production of agar. Its frond dynamics were studied by tagging individual fronds in a typical, dense, monospecific G. sesquipedale stand located in a commercial bed off Cape Espichel, Portugal. Storms and commercial harvesting play a key role in the regulation of the species population dynamics. Frond mortality was relatively constant throughout the year, but peaked in August-September during harvest season. High probabilities of frond breakage and low frond mortality during late fall and winter (periods coincident with severe storms) suggest that under natural disturbances, $G$. sesquipedale fronds break rather than detach. Frond elongation rate shows a distinct seasonal pattern: high during spring and summer and low in winter. The relationships among $G$. sesquipedale vital rates and both size and frond history (i.e. effects of frond length on mortality, growth and breakage, and effects of frond length, growth, breakage and presence of epiphytes on the next month's growth, breakage and mortality) were analysed using log-linear methods. Shorter fronds $(\leq 10.1 \mathrm{~cm})$ were less susceptible to breakage and had higher growth probability than longer fronds, while longer fronds showed higher elongation rates, particularly during the periods of faster growth (late spring and summer). During storms (late fall and winter), longer fronds had a greater chance of being detached than smaller ones. By contrast, during spring and early summer, frond mortality was greater for shorter fronds. There were no clear indications that $G$. sesquipedale recent biological history influenced its fate. Results indicate the potential for yield-overharvesting of the Cape Espichel $G$. sesquipedale bed, because the harvest season starts before peak summer production. Particularly when the previous winter and fall were stormy, as was the case during this study, could better yields be obtained by delaying the harvest season.
\end{abstract}

KEY WORDS: Gelidium sesquipedale - Seaweed Agarophyte Population dynamics - Demography · Vital rates . Size effects - Historical effects

\section{INTRODUCTION}

Gelidium sesquipedale (Clem.) Born. et Thur. is a clonal red alga which grows in the northeast Atlantic subtidal by production of upright fronds from a small, prostrate system of colorless axes, attached to the substrate by rhizoidal protuberances (Dixon 1958, Fan 1961). The species typically forms dense stands of clumped fronds, often under a kelp canopy (Ardré

\footnotetext{
- Present address: Universidade do Algarve, U.C.T.R.A., Gambelas, P-8000 Faro, Portugal
}

1970, Lüning 1990). G. sesquipedale has a triphasic Polysiphonia-type life cycle, with the isomorphic tetrasporophyte and gametophyte phases, plus the small carposporophyte, developing directly on the female thallus (Kylin 1956, Dixon 1959). The tetrasporophyte and female gametophyte can only be distinguished when reproductive. G. sesquipedale is commercially exploited along the coasts of France, Spain, Portugal and Morocco for the production of agar (Santos 1993a). More than half of the world's production of Gelidium is obtained from this species (McLachlan 1985, Armisén \& Galatas 1987). 
Growth rates, generally expressed as size changes, have been studied for many seaweed species (Chapman \& Craigie 1977, 1978, De Wreede 1984, Kain 1987, Ang 1991), as has survivorship, usually reported as cohort depletion curves (e.g. Chapman 1984, Dayton et al. 1984, Schiel 1985, Dean et al. 1989). Growth generally refers to net size variation; influence of thallus breakage component is seldom considered (but see Barilotti \& Silverthorne 1972). Positive and negative changes in frond length are assessed separately in this work and are called growth and breakage respectively.

The influence of an individual's biological history on its fate has been studied in higher plants, particularly in the development of matrix population models (Bierzychudeck 1982, Meagher \& Antonovics 1982, Huenneke \& Marks 1987, Groenendael \& Slim 1988). These are matrix models of first order Markovian processes, i.e. the transition probabilities from time $t$ to $t+1$ depend only upon the individual's state at time $t$, and not upon its state at any previous point in time. In some cases, historical effects are likely to influence an individual's fate (Bierzychudeck 1982, Groenendael \& Slim 1988)

Historical effects in seaweed species have been detected in relation to reproduction. In some species individuals stop growing, and in others individuals degenerate when bearing reproductive structures (Santelices 1978, Dion \& Délépine 1983, Klein 1987). Ang (1992), studying Fucus distichus L., detected a significant negative impact of reproduction on mortality rate in the subsequent time-step, but not on longevity of survivors. The relationships between the fate history of individuals in time $t-1$ and their fate in time $t$ appears to have rarely been addressed in seaweed species. This may be particularly important in red seaweeds that grow by apical cell division, as is the case for Gelidium sesquipedale, where breakage of the thallus may affect future elongation rate (L'HardyHalos 1971).

Because it is difficult to distinguish both adjacent clumps and fronds of the different life cycle phases, Gelidium sesquipedale vital rates were studied here at the frond level, the module sensu Harper (1977), or the metamer sensu White (1979), independent of the prostrate system or life cycle phase. The current study assesses the influence of season and frond length, as well as their interaction, on the vital rates [growth (length increase), breakage (length decrease) and mortality] of $G$. sesquipedale. The strong dependence of vital rates on an individual's size, rather than on age, has been widely documented both for higher plants (see review in Caswell 1989) and for seaweeds (Chapman 1986, Ang 1991). To assess the influence of frond history on vital rates, the effects of frond growth and breakage on frond growth, breakage and mortality of the following time-step are analysed.

Gelidium sesquipedale fronds off the Portuguese coast are often epiphytized in spring and early summer by the annuals Dictyota dichotoma (Hudson) Lamouroux, Plocamium cartilagineum (L.) Dixon and Asparagopsis armata Harvey (pers. obs.). The impact of epiphytism was assessed by analyzing the temporaland size-specific effects of epiphyte presence vs absence on $G$. sesquipedale growth, breakage and mortality of the following time-step. Monthly probabilities of growth, breakage and mortality quantified in this study are parameters in a demographic model constructed for resource management (Santos 1993c), to simulate $G$. sesquipedale recovery from different harvest strategies.

\section{MATERIALS AND METHODS}

This study was conducted in a Gelidium sesquipedale commercial bed off Cape Espichel, Portugal $\left(38^{\circ} 42^{\prime} \mathrm{N}, 9^{\circ} 22^{\prime} \mathrm{E}\right)$. The species occurs in dense stands, particularly in the southern part of the bed, or under the canopy of the kelps Saccorhiza polyschides (Lightfoot) Batters and Laminaria ochroleuca De la Pylaie (Santos 1993b). G. sesquipedale cover is positively correlated to substrate slope and negatively correlated to sediment loading and $S$. polyschides density (Santos 1993b). The study site was on 2 inclined strata in the southern part of the bed, where monospecific $G$. sesquipedale stands spread from 7 to $14 \mathrm{~m}$ in depth (Santos 1993b).

Over 300 fronds, dispersed throughout the study site and covering most of the size spectrum of the species, were haphazardly tagged, using monofilament tags (Sharp \& Tremblay 1985). Lost fronds were continuously replaced, to maintain about 250 observations per sample. Tags were placed on the main axis below the first ramification. The minimum length of a ramified frond was ca $4 \mathrm{~cm}$, and those below this length were not studied due to difficulty in manipulating them under the intense wave surge characteristic of this coast. Tagged frond length was measured monthly from August 1989 through September 1990, except in November, December and February, when excessive wave surge prevented diving. The presence/absence of the epiphytes Dictyota dichotoma, Plocamium cartilagineum and Asparagopsis armata for each tagged frond was recorded.

In this study, a Gelidium sesquipedale frond was considered to have only 3 possible fates during a given time interval: to be detached (mortality), to decrease length (breakage) or to increase length (growth). In a small number of cases, some fronds had zero growth, 
i.e. breakage was equal to growth. In the statistical analysis they were combined with the fronds that decreased in length. The actual mean length increase per unit of time $(30 \mathrm{~d})$ is the elongation rate. It was calculated by grouping all fronds which increased in length during the time interval. Similarly, frond shrinkage rate was calculated for fronds which decreased in length; net elongation rate was calculated by grouping all fronds.

As the absolute time interval (in d) between samples varied, particularly in that period when sea conditions prevented measurement, the percentage fronds that grew, broke or died over each time period was weighted for $30 \mathrm{~d}$, by assuming a linear function for the number of fronds dying in each time interval. Mortality probability per month, $M$, was calculated as:

$$
M=d \times 30 / \Delta t
$$

where $d$ is the number of deaths in time interval $\Delta t$ (in days). Probabilities for frond breakage and growth per month were then calculated assuming the same ratio between them as observed during the time interval between samples. The number of fronds that grew, broke or died per month was calculated by multiplying the initial number of tags in each time period by the respective corrected probability. Gelidium sesquipedale monthly elongation rate, $E$ (or shrinkage rate), was calculated for all fronds that increased (or decreased) in length as:

$$
E=\Delta h \times 30 / \Delta t
$$

where $\Delta h$ is frond length variation.

To assess tag loss rate due to tag decay rather than frond mortality, 30 fronds were double-tagged in August 1989 and followed until March 1990. Loss of only 1 tag was interpreted as tag decay. Mortality estimates were not significantly influenced by tag decay.

Choice of size (length) classes. When dividing a continuous classification character (such as frond length) into categories, the distribution of the observations within categories is affected by the category boundaries chosen. Ideally, all the within-category observations should have the same fate probability (the fate probability of the category center) to minimize the within-category error and to increase differences between categories. Differences in the fate of observations within categories (the 'distribution error' as well as the 'sample error') that occur when too few observations in each category are available were first identified by Vandermeer (1978) in the context of choosing category sizes for transition matrix models. He proposed an algorithm to minimize it, which was later revised and further developed by Moloney (1986). Distribution error is defined by Moloney (1986) as the degree to which the probability that an individual starting in a category will be in the same category in the next time-step deviates from the same probability if all the individuals were aligned in the center of the category. The minimization of the distribution error, as defined by Moloney (1986), selects the distribution of the observations inside a category that will be closest to a central distribution.

Moloney's (1986) algorithm was adapted to derive Gelidium sesquipedale size classes that minimized the distribution error of fronds within length classes (Fig. 1). Three length classes were selected (Fig. 1). Class SI fronds were $\leq 10.1 \mathrm{~cm}$ length, class SII fronds were $>10.1 \mathrm{~cm}$ and $\leq 16.0 \mathrm{~cm}$ and class SIII fronds were $>16.0 \mathrm{~cm}$. Classes were selected keeping the number of observations of fate (breakage class BI: negative or zero length variation; breakage class BII: positive length variation or deaths; growth class GI: positive length variation; growth class GII: breakage or deaths; mortality class MI: deaths; mortality class MII: survivors) and elongation rate (class EI: $\leq 0.5 \mathrm{~cm} \mathrm{mo}^{-1}$; class EII: $>0.5$ and $\leq 1.0 \mathrm{~cm} \mathrm{mo}^{-1}$; class EIII: $>1.0 \mathrm{~cm}$ $\mathrm{mo}^{-1}$ ) equal to or higher than 5 in at least $80 \%$ of the cases (an assumption of contingency tables) for all time-steps.

Data analysis. Discrete categorical data, such as frond breakage/growth, mortality/survival, presence/ absence of epiphytes, are most appropriately analysed using log-linear models (Bishop et al. 1975, Fienberg 1979). Caswell (1989) gives a detailed description of how to use this analysis to choose state variables for demographic models. In the current study, log-linear

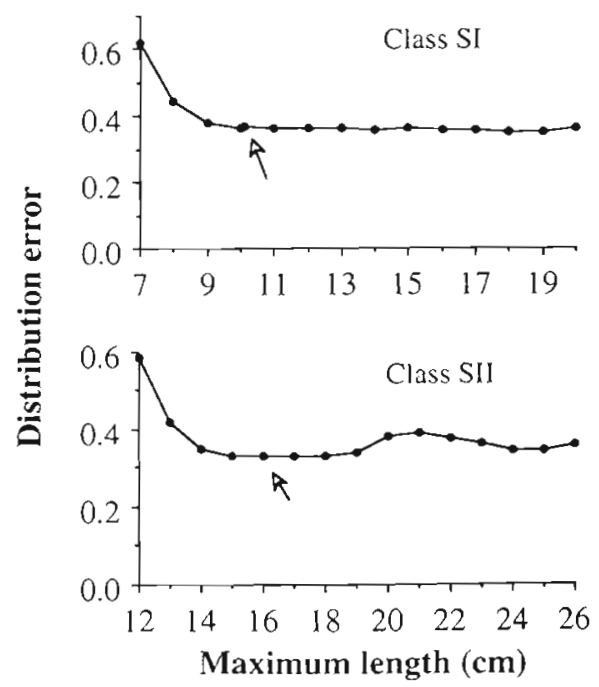

Fig. 1. Gelidium sesquipedale. Distribution error for red algae determining length classes. Each value shows the distribution error (Moloney 1986) of fronds within potential length classes. Arrows show the upper limits selected for class SI and SII. Class boundaries were selected so that both the distribution error was low and the number of observations within a class was significant (see text) 
analysis is used to test statistical interactions of the explanatory variables time and size, with both frond fate and elongation rate, as well as the contribution of each when the other (time or size) is included in the model. In a log-linear model, an interaction term represents association between categorical variables. i.e. the combined effect of these variables on cell frequency. The statistical significance of an interaction is assessed by comparing the goodness of fit of the model $(\log$ likelihood ratio, $G$ ) following the addition or deletion of that term from the model (Caswell 1989). For example, to test if size provides additional information to time about mortality, the change in $G$ of the model

Time $\times$ Size + Time $\times$ Mortality + Size $\times$ Mortality

when compared to the model

$$
\text { Time } \times \text { Size }+ \text { Time } \times \text { Mortality }
$$

was examined. The difference among the $G$ values and degrees of freedom between the 2 models gives the statistical significance of the effect of size on mortality given the contribution of time, $\mathrm{S} \times \mathrm{M} / \mathrm{T}$.

The historical effects of frond fate, elongation rate and epiphyte presence on the next time-step frond fate and elongation rate are also analysed. In this analysis, breakage and growth are considered the only possible initial frond fates (breakage probability + growth probability $=1$ ), as opposed to the previous analysis where mortality is also a possible fate (breakage probability + growth probability + mortality probability $=1$ ). The impact of epiphytes was tested only for the period April through September 1990, when epiphytism was heavy. All data analyses were done using SYSTAT 5.1 for Macintosh (Wilkinson 1989).

\section{RESULTS}

\section{Gelidium sesquipedale frond dynamics}

The temporal variation of Gelidium sesquipedale frond fate probability (Fig. 2) was highly significant $(\mathrm{p}<0.001)$, with or without the inclusion of frond size in the $\log$-linear models $(T \times M, T \times M / S, T \times B, T \times B / S$, $T \times G$ and $T \times G / S$; Table 1$)$. Frond mortality was relatively constant throughout the year, with the exception of August-September 1990 (Fig, 2), which had a high value $(0.56)$. The tagged fronds may have been removed by professional harvesters, as the study site was open to harvesting. The open season begins in the middle of July, and continues through the summer and fall (Santos \& Duarte 1991). High mortality was not observed during the 1989 season because the study site was harvested prior to the tagging experiment.

August-September 1990 mortality values may be

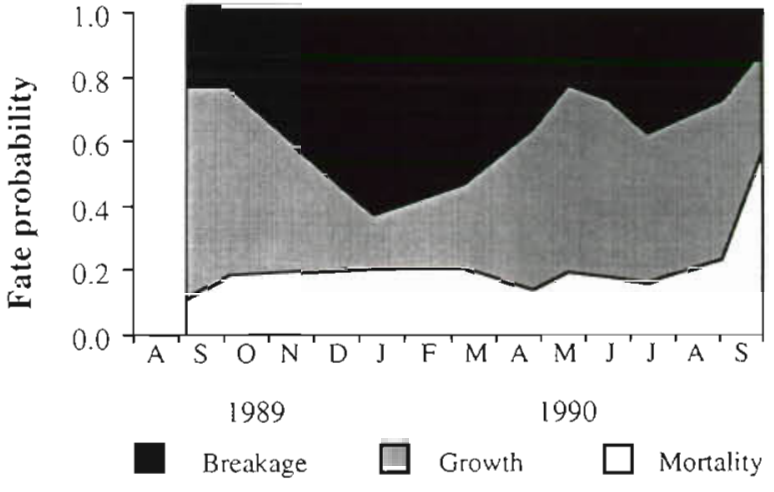

Fig. 2. Gelidium sesquipedale. Temporal changes of frond fate probability: breakage (negative or zero length increase), growth (positive length increase) and mortality

overestimated because of the tagged fronds not found by divers in September. This occurred every sampling, but was corrected on following samplings when some missing tagged fronds were found. The average percentage of missing fronds per sample was $5.5 \%$. Even considering the maximum percentage of missing fronds per sample, $14.9 \%$, the resulting corrected mortality probability, ca 0.43 , is still higher than the previous month's value, 0.23 , supporting the hypothesis of an important harvest mortality during this period.

Table 1. Statistical significance (log likelihood ratio, $G$ ) for the interactions of time and size with Gelidium sesquipedale vital rates. See 'Methods' for explanation of log-linear models. $\mathrm{T}$ : time (10 categories); S: length ( $\mathrm{SI} \leq 10 \mathrm{~cm}$, SII $>10.1$ and $\leq 16.0 \mathrm{~cm}$, SIII $>16.0 \mathrm{~cm}$ ); : mortality $/$ survival; B: breakage/no breakage ${ }_{i}$ G: growth/no growth; $E$ : elongation rate (EI $\leq 0.5 \mathrm{~cm} \mathrm{mo}^{-1}$. EII $>0.5$ and $\leq 1.0 \mathrm{~cm} \mathrm{mo}^{-1}$. EIII $>1.0 \mathrm{~cm}$ $\mathrm{mo}^{-1}$ ); Ep: epiphytes/no epiphytes

\begin{tabular}{lrrr|}
\hline Model & $G$ & df & $p$ \\
\hline $\mathrm{T} \times \mathrm{M}$ & 205.35 & 9 & $<0.001$ \\
$\mathrm{~T} \times \mathrm{M} / \mathrm{S}$ & 207.16 & 9 & $<0.001$ \\
$\mathrm{~T} \times \mathrm{B}$ & 140.25 & 9 & $<0.001$ \\
$\mathrm{~T} \times \mathrm{B} / \mathrm{S}$ & 196.35 & 9 & $<0.001$ \\
$\mathrm{~T} \times \mathrm{G}$ & 287.05 & 9 & $<0.001$ \\
$\mathrm{~T} \times \mathrm{G} / \mathrm{S}$ & 294.45 & 9 & $<0.001$ \\
$\mathrm{~T} \times \mathrm{E}$ & 132.94 & 9 & $<0.001$ \\
$\mathrm{~T} \times \mathrm{E} / \mathrm{S}$ & 294.45 & 9 & $<0.001$ \\
$\mathrm{~T} \times \mathrm{Ep}$ & 314.63 & 4 & $<0.001$ \\
$\mathrm{~T} \times \mathrm{Ep} / \mathrm{S}$ & 333.76 & 4 & $<0.001$ \\
$\mathrm{~S} \times \mathrm{M}$ & 3.96 & 2 & 0.138 \\
$\mathrm{~S} \times \mathrm{M} / \mathrm{T}$ & 5.77 & 2 & 0.056 \\
$\mathrm{~S} \times \mathrm{B}$ & 39.49 & 2 & $<0.001$ \\
$\mathrm{~S} \times \mathrm{B} / \mathrm{T}$ & 42.49 & 2 & $<0.001$ \\
$\mathrm{~S} \times \mathrm{G}$ & 40.26 & 2 & $<0.001$ \\
$\mathrm{~S} \times \mathrm{G} / \mathrm{T}$ & 47.66 & 2 & $<0.001$ \\
$\mathrm{~S} \times \mathrm{E}$ & 40.26 & 2 & $<0.001$ \\
$\mathrm{~S} \times \mathrm{E} / \mathrm{T}$ & 47.66 & 2 & $<0.001$ \\
$\mathrm{~S} \times \mathrm{Ep}$ & 71.68 & 2 & $<0.001$ \\
$\mathrm{~S} \times \mathrm{Ep} / \mathrm{T}$ & 90.81 & 2 & $<0.001$ \\
\hline
\end{tabular}




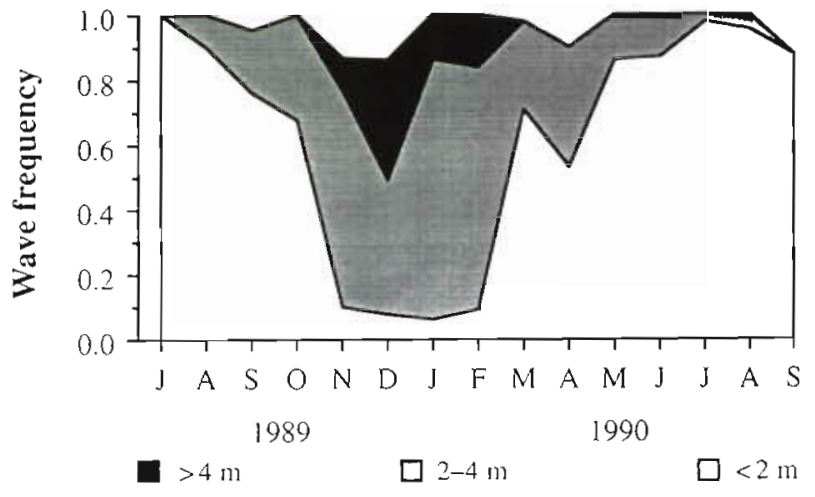

Fig. 3. Monthly probabilities for the occurrence of waves of certain heights off Cape Espichel, Portugal. Wave data were obtained with wave simulation model MAR211, from Instituto

Nacional de Meteorologia e Geofísica, Lisboa, Portugal

High probabilities for frond breakage were observed throughout the year (Fig. 2). Frond breakage attained highest values during late fall and winter months, when severe storms with waves up to $7 \mathrm{~m}$ high occurred off Cape Espichel (Fig. 3). A smaller breakage peak occurred in June-July 1990 prior to the harvest season (Fig. 2). On the other hand, frond growth probability was low in winter. All fronds were probably increasing in length, but breakage was high during this period. Frond growth probability was high through late spring and summer, except in AugustSeptember 1990 due to harvest mortality.

\section{Length variation}

The temporal variation of Gelidium sesquipedale elongation rate is highly significant, with or without

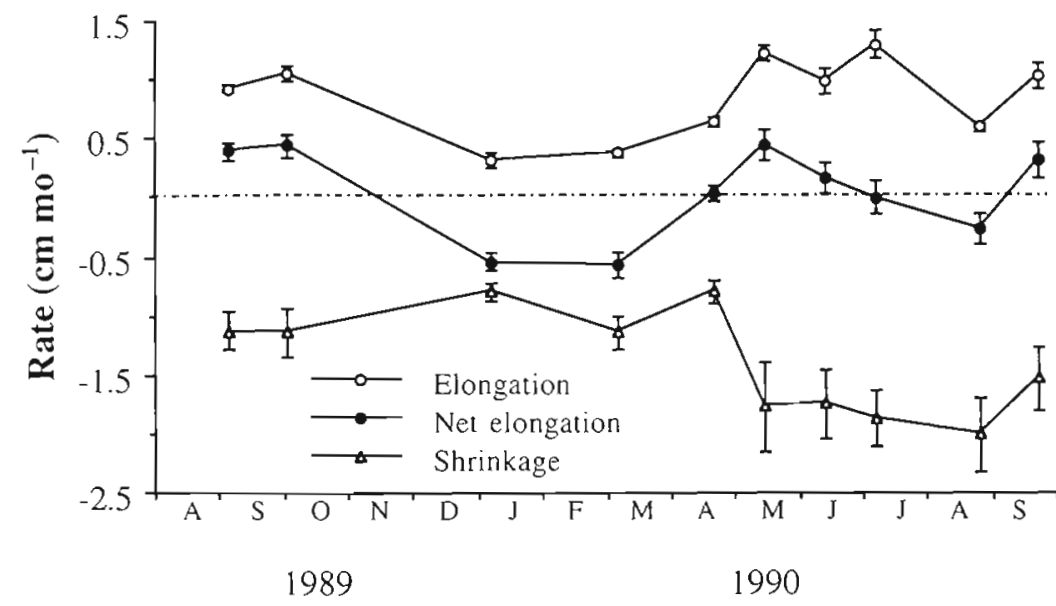

Fig. 4. Gelidium sesquipedale. Mean intermonthly variation of frond length. Vertical bars are standard errors. Elongation rate was calculated by grouping all fronds that increased in length, shrinkage rate by grouping all fronds with negative or zero growth and net elongation rate by grouping all fronds the contribution of size $(\mathrm{T} \times \mathrm{E}$ and $\mathrm{T} \times \mathrm{E} / \mathrm{S}$; Table 1$)$. Elongation rate shows a distinct seasonal pattern; it was high during spring and summer months (ca $1 \mathrm{~cm}$ $\mathrm{mo}^{-1}$ ), while during late fall and winter, it decreased to a minimum of $0.3 \pm 0.07 \mathrm{~cm} \mathrm{mo}^{-1}( \pm \mathrm{SE})$ for the period January through March 1990 (Fig. 4). The maximum elongation rate observed was $1.3 \pm 0.07 \mathrm{~cm} \mathrm{mo}^{-1}$, in June-July 1990, just before the open harvest season. A sudden decrease was observed in July-August 1990. Elongation recovered to normal summer values during September.

Gelidium sesquipedale frond shrinkage was low during fall and winter, and increased during late spring and summer (Fig. 4), when fronds were longer. Frond net elongation rate was negative during late fall and winter, and positive during spring and summer, except in July-August 1990. The decrease in net elongation rate from May to August 1990 was due to important losses of frond material (breakage probability and shrinkage rate; Figs. $2 \& 4$ ).

\section{Effects of size}

The effects of Gelidium sesquipedale frond length on breakage and growth probabilities were highly significant $(p<0.001)$, with or without the contribution of time $(\mathrm{S} \times \mathrm{B}, \mathrm{S} \times \mathrm{B} / \mathrm{T}, \mathrm{S} \times \mathrm{G}$ and $\mathrm{S} \times \mathrm{G} / \mathrm{T}$; Table 1$)$. Shorter fronds $(\leq 10.1 \mathrm{~cm})$ were less susceptible to breakage and had a greater chance of increasing in length than longer fronds (Fig. 5). The effect of length on mortality was not significant $(\mathrm{p}>0.05, \mathrm{~S} \times \mathrm{M}$ and $\mathrm{S} \times \mathrm{M} / \mathrm{T}$; Table 1 . Fig. 5).

The effect of frond size on elongation rate was also highly significant ( $p<0.001, \mathrm{~S} \times \mathrm{E}$ and $\mathrm{S} \times \mathrm{E} / \mathrm{T}$; Table 1).

Fig. 6 shows the frequency distribution of elongation rate classes for each frond length class. The frequency of fronds elongating more than $1 \mathrm{~cm}$ $\mathrm{mo}^{-1}$ increased with length, in contrast with those elongating less (Fig. 6A). This effect is even more evident during periods of rapid length increase (August to October 1989, April to July 1990 and August to September 1990), when $50 \%$ of the fronds longer than $16 \mathrm{~cm}$ grew more than 1 $\mathrm{cm} \mathrm{mo}^{-1}$ (S $\times \mathrm{E}: G=21.1, \mathrm{df}=4, \mathrm{p}<$ $0.001 ; \mathrm{S} \times \mathrm{G} / \mathrm{T}: G=19.0$, df $=4, \mathrm{p}=$ $0.001)$, as opposed to shorter fronds which grew significantly less (Fig. 6B).

During periods of slow growth (OCtober 1989 to May 1990 and July to August 1990), the effects of frond length on elongation rate do not 


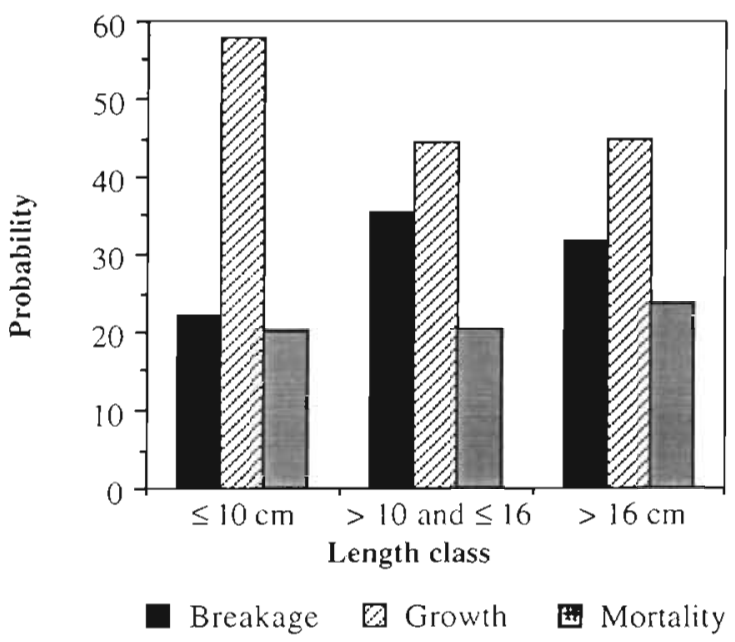

Fig. 5. Gelidium sesquipedale. Effect of frond length on frond breakage $(\mathrm{S} \times \mathrm{M} / \mathrm{T}, \mathrm{p}<0.001)$, growth $(\mathrm{S} \times \mathrm{M} / \mathrm{T}, \mathrm{p}<0.001)$ and mortality $(\mathrm{S} \times \mathrm{M} / \mathrm{T}, p=0.056)$ probabilities. Size class SI: fronds $\leq 10.1 \mathrm{~cm}$; SII: fronds $>10.1$ and $\leq 16 \mathrm{~cm}$; SIII: fronds $>16 \mathrm{~cm}$

appear significant (Fig. 6C). High incidence of breakage during these periods resulted in low cell counts, particularly of size class SIII fronds. Log-linear tests of significance are not valid in these cases.

Although the effects of size on frond mortality were not significant when all months were considered in the analysis (Table 1), for the periods when Gelidium sesquipedale was subjected to strong physical disturbances such as storms or harvesting (August 1989 to March 1990 and July to September 1990), frond length did have a significant effect on mortality $(\mathrm{S} \times \mathrm{M}: G=20.2, \mathrm{df}=2, \mathrm{p}<0.001 ; \mathrm{S} \times \mathrm{M} / \mathrm{T}: G=20.6$, $\mathrm{df}=2, \mathrm{p}<0.001$ ). Longer fronds had a greater chance of being detached from the substratum than smaller fronds (Fig, 7). Conversely, in March to July 1990 mortality was significantly higher $(\mathrm{S} \times \mathrm{M}: G=12.0$, df $=2, \mathrm{p}=0.002 ; \mathrm{S} \times \mathrm{M} / \mathrm{T}: G=10.9, \mathrm{df}=2, \mathrm{p}=0.004$ ) for size class SI fronds than for SII and SIII fronds (Fig. 7).

\section{Epiphytes}

The epiphytes Dictyota dichotoma, Plocamium cartilagineum and Asparagopsis armata occurred on Gelidium sesquipedale fronds in May and June 1990 (Fig. 8), when ca $20 \%$ of the fronds were epiphytized. In the following month, a sudden increase in epiphytebearing fronds was observed, particularly for frond size classes SII and SIII. Longer G. sesquipedale fronds were more epiphytized than were shorter fronds (Fig. 8); $52 \%$ of size class SI fronds had epiphytes in July, compared with $81 \%$ and $88 \%$ of class SII and
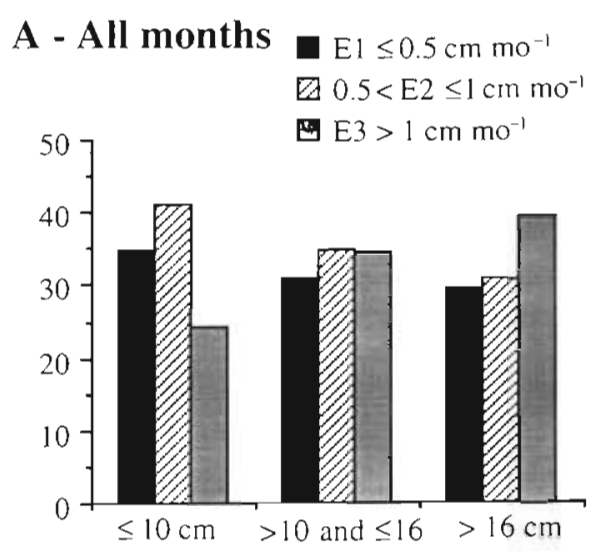

\section{B - High rate periods}

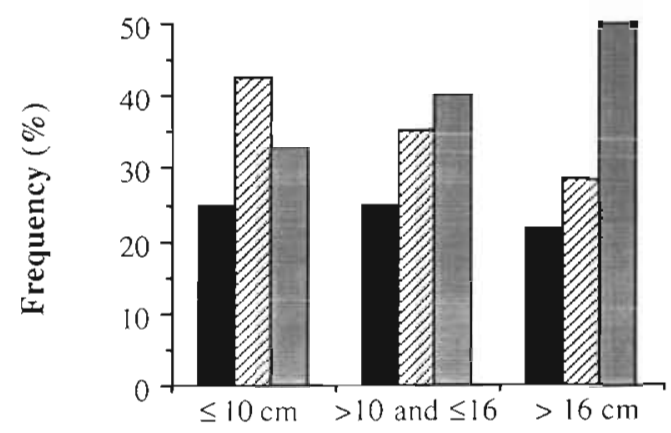

C - Low rate periods

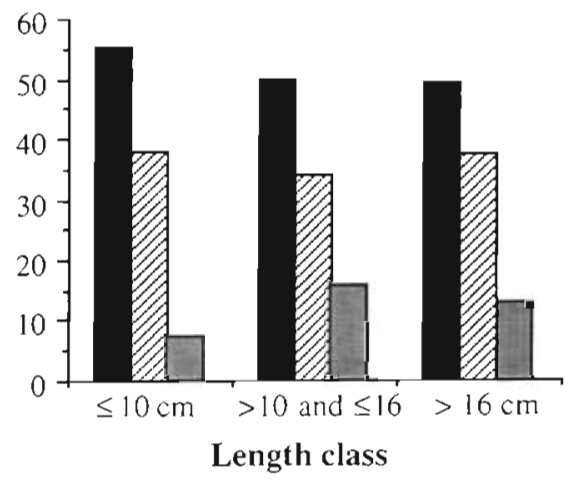

Fig. 6. Gelidium sesquipedale. Effects of frond length on frond elongation rate. (A) All months ( $\mathrm{S} \times \mathrm{M} / \mathrm{T}, \mathrm{p}<0.001$ ). (B) Only the periods of high elongation rate: Aug to Oct 1989, Apr to Jul 1990 and Aug to Sep 1990 (S×M/T, p < 0.001). (C) Only periods of low elongation rate: Oct to May 1990 and Jul to Aug 1990 (tests of significance are not valid, see text)

SIII fronds respectively. Epiphytism slowly decreased through September. Both time period and size effects on $G$. sesquipedale epiphyte load are highly significant, even when effects of the other variable are included in the log-linear models $(T \times E, T \times E / S, S \times E$ and $\mathrm{S} \times \mathrm{E} / \mathrm{T}$; Table 1 ). 


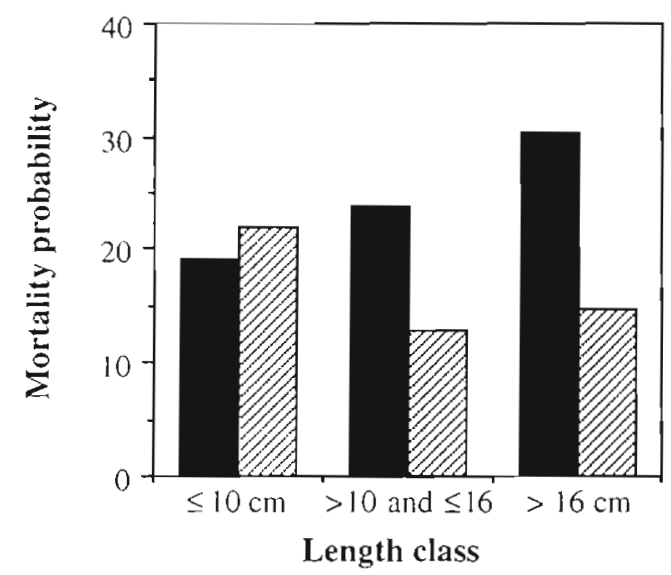

Fig. 7. Gelidium sesquipedale. Seasonal effect of frond length on frond mortality. Solid bars indicate periods of harvest and natural (storm) disturbances. Aug 1989 to Mar 1990 and Jul to Sep $1990(\mathrm{~S} \times \mathrm{M} / \mathrm{T}, \mathrm{p}<0.001)$. Hatched bars indicate spring and early summer period Mar to Jul $1990(\mathrm{~S} \times \mathrm{M} / \mathrm{T}, \mathrm{p}=0.04)$

\section{Effects of historical events}

The recent biological history of a Gelidium sesquipedale frond may play an important role on its fate, and thus on the regulation of its demography. The fate and elongation rate of a $G$. sesquipedale frond during the time-step $t$ to $t+1$, that broke during the time-step $t-1$ to $t$ may be different than had the frond not broken. The significance of these relationships, tested by log-linear analysis, is shown in Table 2. Models with or without the contribution of both time and size are presented. In this analysis, only 2 categories of length (class S-a: $\leq 13 \mathrm{~cm}$; class $\mathrm{S}-\mathrm{b}:>13 \mathrm{~cm}$ ) and elongation rate (class E-a: $\leq 0.75 \mathrm{~cm} \mathrm{mo}^{-1}$; class E-b: $>0.75 \mathrm{~cm}$ $\mathrm{mo}^{-1}$ ) were considered, so that cells of contingency tables have the maximum number of counts. Unfortunately, some cells are still sparse (frequency $<5$ in

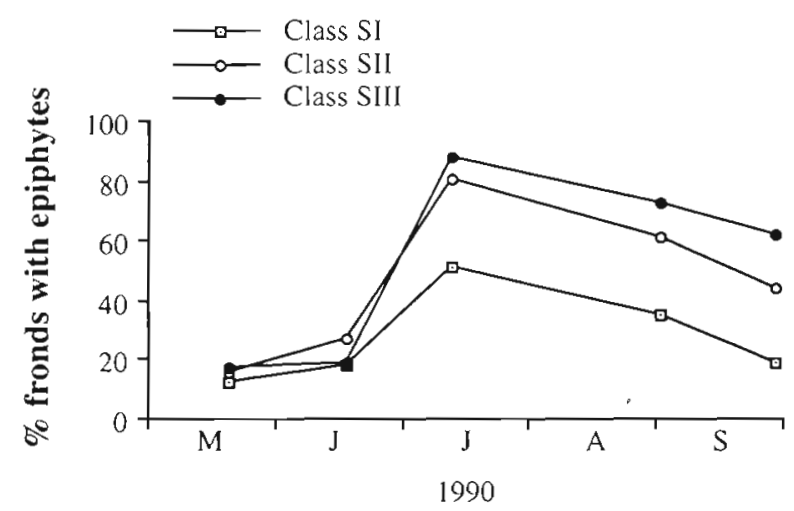

Fig. 8. Gelidium sesquipedale. Percentage of fronds per length class bearing epiphytes. Size class SI: fronds $\leq 10.1 \mathrm{~cm}$; SII: fronds $>10.1$ and $\leq 16 \mathrm{~cm}$; SIII: fronds $>16 \mathrm{~cm}$
Table 2. Gelidium sesquipedale. Statistical significance (log likelihood ratio, $G$ ) of the effects of historical events on frond fate. Variables followed by 1 are of the next time-step. T: time (10 categories); $\mathrm{S}$ : length $(\mathrm{S}-\mathrm{a} \leq 13.0 \mathrm{~cm}, \mathrm{~S}-\mathrm{b}>13.0 \mathrm{~cm}) ; \mathrm{M}$ : mortality/survival; $B$ : breakage/growth; $E$ : elongation rate (E-a $\leq 0.75, E-b>0.75 \mathrm{~cm} \mathrm{mo}^{-1}$ ); Ep: epiphytes/no epiphytes. Asterisks show if one (") or both (") log-linear models have sparse cells (see text). See 'Methods' for explanation of loglinear models

\begin{tabular}{|lccc|}
\hline Model & $G$ & $\mathrm{df}$ & $\mathrm{p}$ \\
\hline $\mathrm{B} \times \mathrm{M} 1$ & & 1 & 0.027 \\
$\mathrm{~B} \times \mathrm{M} 1 / \mathrm{T}, \mathrm{S}$ & 4.87 & 1 & 0.325 \\
$\mathrm{~B} \times \mathrm{B} 1$ & 0.97 & 1 & 0.008 \\
$\mathrm{~B} \times \mathrm{B} 1 / \mathrm{T}, \mathrm{S}$ & 7.13 & 1 & 0.163 \\
$\mathrm{~B} \times \mathrm{E} 1$ & 1.95 & 1 & $<0.001$. \\
$\mathrm{B} \times \mathrm{E} 1 / \mathrm{T}, \mathrm{S}$ & 24.13 & 1 & $<0.001$. \\
$\mathrm{E} \times \mathrm{B} 1$ & 20.32 & 1 & $<0.001$ \\
$\mathrm{E} \times \mathrm{B} 1 / \mathrm{T}, \mathrm{S}$ & 17.56 & 1 & $<0.001$. \\
$\mathrm{E} \times \mathrm{E} 1$ & 25.4 & 1 & $0.663 \cdots$ \\
$\mathrm{E} \times \mathrm{E} 1 / \mathrm{T}, \mathrm{S}$ & 0.19 & 1 & 0.647 \\
$\mathrm{E} \times \mathrm{M} 1$ & 0.21 & 1 & 0.173 \\
$\mathrm{E} \times \mathrm{M} 1 / \mathrm{T}, \mathrm{S}$ & 1.86 & 1 & 0.317. \\
$\mathrm{Ep} \times \mathrm{B} 1$ & 1.00 & 1 & 0.517 \\
$\mathrm{Ep} \times \mathrm{B} 1 / \mathrm{T}, \mathrm{S}$ & 0.42 & 1 & 0.251 \\
$\mathrm{Ep} \times \mathrm{E} 1$ & 1.32 & 1 & $0.888 \cdot$. \\
$\mathrm{Ep} \times \mathrm{E} 1 / \mathrm{T}, \mathrm{S}$ & 0.02 & 1 & $0.59 \cdot$ \\
$\mathrm{E} \mathrm{M} \times \mathrm{M} 1$ & 0.29 & 1 & $<0.001$ \\
$\mathrm{Ep} \times \mathrm{M} 1 / \mathrm{T}, \mathrm{S}$ & 40.48 & 1 & 0.462 \\
\hline
\end{tabular}

more than one-fifth of the cells). The significance tests in these cases are suspect. They are marked with 1 or 2 asterisks (Table 2), respectively, if one or both loglinear models used to calculate the interaction have sparse cells.

Significant relationships were detected between breakage and the next time-step mortality $(\mathrm{B} \times \mathrm{M} 1, \mathrm{p}=$ 0.027 ), between breakage and next time-step breakage $(B \times B 1, p=0.008)$, and between epiphyte presence and next time-step mortality (Ep $\times M 1, p<0.001)$, but these were caused by time- and size-related variability. When time and size contributions are accounted for, these relationships are not significant $(B \times M 1 / T, S$, $\mathrm{p}=0.325 ; \mathrm{B} \times \mathrm{B} 1 / \mathrm{T}, \mathrm{S}, \mathrm{p}=0.163 ; \mathrm{Ep} \times \mathrm{M} 1 / \mathrm{T}, \mathrm{S}, \mathrm{p}=0.462)$.

On the other hand, Gelidium sesquipedale fronds that break in one time-step appear to have lower elongation rates during the next time-step than unbroken fronds (Fig. 9A). In addition, fronds that elongate faster in one time-step have a greater probability of growing than breaking during the next time-step (Fig. 9B). These effects were significant given the time and size contributions $(B \times E 1 / T, S, p<0.001 ; E \times B 1 / T, S, p<$ 0.001 ), but in both cases 1 of the 2 log-linear models used to test the effect is based on a small sample size (Table 2).

The presence of epiphytic algae on Gelidium sesquipedale did not significantly influence the fate of fronds in the next time-step, except for frond mortality prob- 


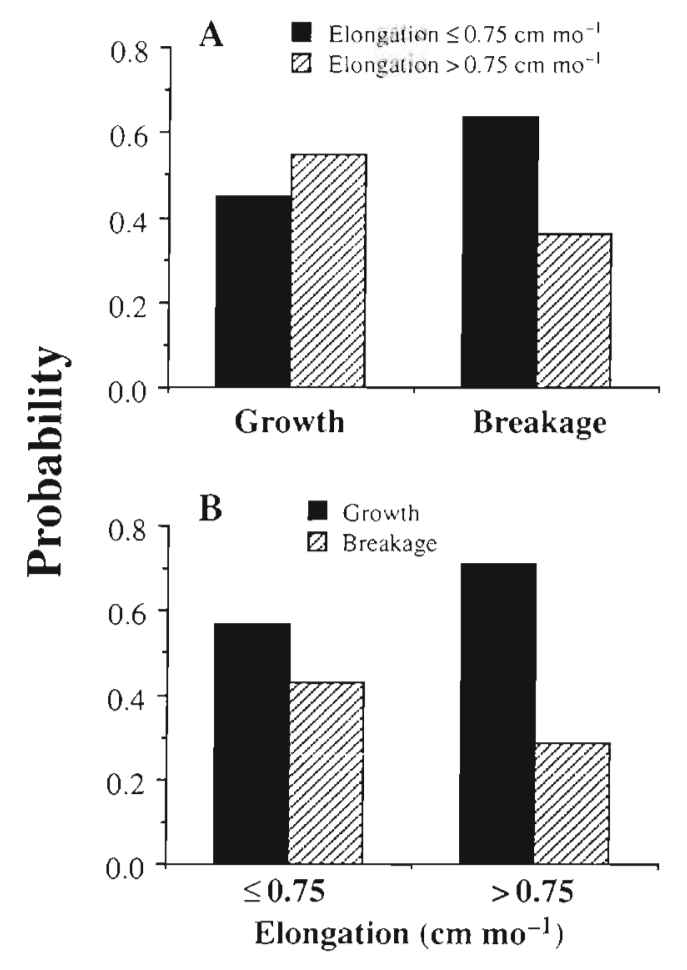

Fig. 9. Gelidium sesquipedale. Effects of frond history on vital rates. (A) Effect of breakage/growth probability (time $t$ ) on elongation rate (time $t+1)$ ( 1 model of significance tests has sparse cells, see text). (B) Effects of elongation rate (time $t$ ) on breakage/growth probability (time $t+1)(\mathrm{E} \times \mathrm{B} 1, \mathrm{p}<0.001$; in $\mathrm{E} \times \mathrm{B} 1 / \mathrm{T}, 1$ model has sparse cells, see text)

ability (Table 2). However, this relationship is not significant when both time and size are accounted for $(E p \times M 1 / T, S, p=0.462)$. In order to assess if the attachment and development of epiphytic spores is enhanced by the increase of damaged zones on $G$. sesquipedale fronds after breakage, the relationship between frond breakage and the next time-step epiphyte presence was also tested. The relationship was not significant given the effects of time and size $(B \times E p 1, p=0.014$; $\mathrm{B} \times \mathrm{Ep} 1 / \mathrm{T}, \mathrm{S}, \mathrm{p}=0.920$ ).

\section{DISCUSSION}

\section{Seasonal dynamics}

Both harvest and natural (storm) disturbances play an important role on the seasonal changes of Gelidium sesquipedale frond fate. Frond mortality was relatively constant throughout the year, but peaked in August-September due to harvest. Storms, in contrast to the harvest, caused more frond breakage than frond mortality. High probabilities of frond breakage and low frond mortality during late fall and winter, periods coincident with strong wave surge, suggest that under natural disturbances, $G$. sesquipedale fronds break rather than detach. This appears to be an adaptation to environments of intense wave-induced physical stress, which is the typical habitat for Gelidiales species (Santelices 1988). Large quantities of stormtossed $G$. sesquipedale fronds occur during fall and winter throughout the species' geographical distribution. This phenomenon is well documented because the harvest on shore provides raw material to the agar industry (Seoane-Camba 1969, Juanes \& Borja 1991, Santos 1993a). Of the storm-tossed material, 65 to $92 \%$ are broken fronds, lacking the basal portion of the axis (Seoane-Camba 1966). However, this was not the case for Gelidium robustum (Gard.) Holl. et Abbott in California, USA, where frond breakage was rare (Silverthorne 1977).

Frond breakage plays an important role in Gelidium sesquipedale production dynamics. Although fronds grow throughout the year, net elongation rate was negative both during periods of severe sea storms and during July and August 1990 (Fig. 4), due to significant losses of frond material (Figs. 2 \& 4). During late spring and summer, when wave surge is low (Fig. 3), frond breakage is probably caused by grazing. Grazing by invertebrates and fishes was not controlled during this experiment, but their activity has been reported as causing extensive trimming of $G$. sesquipedale in Santander, Spain, by weakening axes and making them more susceptible to breakage by wave action (Salinas et al. 1976, Reguera et al. 1978). The latter study observed that more broken fronds were found in spring, coincident with a high abundance of grazers.

The importance of frond breakage on regulating the yields of Gelidium sesquipedale is enhanced due to the species' low elongation rate (see Lüning 1990, p. 364, for examples of maximal growth rates of seaweeds), a feature that appears to be characteristic of Gelidiales (Stewart 1983, Santelices 1988). At Cape Espichel, elongation rate was low in late fall and winter $(0.31 \pm$ 0.067 and $0.34 \pm 0.034 \mathrm{~cm} \mathrm{mo}^{-1}( \pm \mathrm{SE}$ ) respectively) and peaked at $1.30 \pm 0.12 \mathrm{~cm} \mathrm{mo}^{-1}$ during June-July. These values are similar to elongation rates of $G$. sesquipedale fronds at other localities (Seoane-Camba 1966, Gorostiaga 1990).

In most Gelidiales, and particularly for Gelidium sesquipedale (Seane-Camba 1966. Gorostiaga 1990), the favorable production seasons are late spring and summer (Fig. 4). During this period, even though frond shrinkage was highest, net elongation was positive due to low frond breakage probability (Fig. 2). An accurate measure of tissue loss for production estimates cannot be derived based on frond length decrease because shedding of branches (accounting for 
important biomass lossesj may occur, while the main axis remains intact.

\section{Effects of size}

Longer Gelidium sesquipedale fronds are more vulnerable to detachment during harvesting and storms than shorter fronds (Fig. 7). Maximum harvest mortality estimates (Santos 1993c) show that longer fronds are particularly vulnerable to harvest. By contrast, during spring and early summer, frond mortality is greater for shorter fronds. This may be a result of densitydependent self-thinning, following the period of January to April 1990 when there was a rapid density increase due to a recruitment peak (Santos 1993a). In high-density monospecific stands of land plants, it was observed that intense intraspecific competition causes mortality of small suppressed individuals (Weiner \& Thomas 1986). Dean et al. (1989) and Reed (1990) suggest that higher mortality of small kelp fronds in these conditions is the result of intraspecific competition for light.

The effect of frond size on elongation rate in Gelidiales has seldom been addressed. At Cape Espichel, Gelidium sesquipedale elongation rate was related to frond length, particularly during periods of high production (Fig. 4). Longer fronds grew faster than shorter fronds, suggesting a density-dependent mechanism of growth suppression of shorter fronds by longer fronds. $G$. sesquipedale increases its length by the division of the apical cell (Rodriguez \& Santelices 1987). In crowded conditions, light is more available to the apical portion of longer fronds than to shorter ones. In addition, nutrient availability may be lower to shorter fronds due to reduced water movement beneath the canopy. During periods of slow growth (Fig. 4), there was no indication of size effect on elongation rate (Fig. 6C).

Gorostiaga's (1990) data on Gelidium sesquipedale elongation rates show significant positive correlations with frond length throughout the year. Guzmán del Próo \& de la Campa de Guzmán's (1979) indicated the same relationship for G. robustum off Baja California, Mexico, but the elongation rates for the different size classes were measured in different years. The net elongation rates of size class 11 to $24 \mathrm{~cm}$ were consistently higher throughout 1968 and 1969 than those of size class 9 to $13 \mathrm{~cm}$ during 1970 and 1971 , except in the periods when net elongation rates of longer fronds were negative, while that of the smaller fronds was positive (Tables 1 \& 2 in Guzmán del Próo \& de la Campa de Guzmán 1979). However, Barilotti \& Silverthorne (1972) reported elongation rates of $9 \mathrm{~cm} \mathrm{yr}^{-1}$ for intact $G$. robustum fronds off California, and no significant correlation between elongation rate and frond length.

\section{Historical effects}

There were only slight indications that Gelidium sesquipedale recent biological history influenced its fate. Epiphytes growing on G. sesquipedale were abundant during summer months (Fig. 9), particularly on longer fronds, but did not seem to affect frond growth or survival (Table 2). Faster-growing fronds may have a higher probability of growing than breaking during the next time-step, and frond breakage may slow down elongation rate (Fig. 8), but the number of observations was too low to have conclusive statistical significance.

Gelidium sesquipedale fronds under more favorable microenvironmental conditions, such as exposure to light, patterns of water flow, or neighborhood effects, may have higher growth rates and longer growth periods before breaking or dying. Reduced growth immediately after breakage could be due to a delay caused by the physiological process of initiating regeneration. Apical regeneration on broken fronds has been reported for several Gelidium species (Johnstone \& Feeney 1944, Barilotti \& Silverthorne 1972, Salinas et al. 1976, Reguera et al. 1978). Gelidium and Pterocladia species have a uniaxial structure and grow by division of the apical cell (Kylin 1956, Dixon 1958, Fan 1961). When the apical cell is lost, cortical cells differentiate into apical cells (Felicini \& Arrigoni 1967, Felicini 1970) and develop an indeterminate growth axis (Dixon 1973). One or more axis can develop from the cut surface, probably modifying frond morphology.

Lower elongation rate of broken fronds would explain the unexpected low elongation rate in JulyAugust 1990 during the favorable growing season (Fig, 4), because it follows a period of high breakage probability (Fig. 2). This effect was not observed by other authors. Seoanne-Camba (1966) did not detect differences between elongation of sheared and intact Gelidium sesquipedale axis along the western coast of Spain. Johnstone \& Feeney (1944) observed apical regeneration of cut fronds of $G$. robustum off California in spring and late fall, following periods of intense surf. The authors speculated that growth was higher as a reaction to frond injuries, but did not measure it.

Gelidium sesquipedale frond breakage is probably the most important demographic parameter on regulating population yields, particularly in stormy years, as was the case in this study. In less severe years, frond material lost by breakage may be lower, thus increasing available yields for commercial harvest. Nevertheless, $G$. sesquipedale frond breakage is a common event during fall and winter. Salinas et al. (1976) observed that almost all $G$. sesquipedale fronds longer than $3 \mathrm{~cm}$ on the coast of Santander, Spain, showed signs of regrowth from previous axis breakage. 
There is a potential for yield overharvesting of the Cape Espichel Gelidium sesquipedale bed, as is the case for Chondrus crispus Stackhouse exploitation in Canada's Prince Edward Island (Chopin et al. (1992). Harvesting by divers in the middle of July, as is done in Portugal (Santos \& Duarte 1991), may reduce yields because the peak summer production is lost. Monitoring of frond length structure could help to decide the best timing to open the season. Particularly when the previous winter and fall were stormy, better yields could be obtained by delaying the harvest season. Sociological and technological aspects limiting the rapid completion of harvest before fall storms must be considered. Due to the slow growth of the species, it is not likely that sites which have already been harvested can be re-harvested later in the season.

Ackowledgements. I thank P. Duarte and A. Morais for their assistance during many months of field and laboratory work. Comments by J. Pringle, G. Sharp and A. R. O. Chapman in the first stages of the research are appreciated. J. Pringle, G. Sharp, S. Walde, P. Ang, R. de Wreede and B. Santelices critically read different versions of the manuscript, greatly improving it. The research was funded by Laboratorio Nacional de Engenharia e Tecnologia Industrial through Dr C. Peneda's grant, to whom I am particularly grateful. A. Junta Nacional de Investigaçào Científica e Tecnológica scholarship (BIC $n^{\circ} 402$ ), a Government of Canada Award, and a Lett Bursary of Dalhousie University supported my stay in Canada. The Halifax Fisheries Research Laboratory provided the conditions, as well as an excellent working environment, for data analyses and writing.

\section{LITERATURE CITED}

Ang, P. O. (1991). Age- and size-dependent growth and mortality in a population of Fucus distichus. Mar. Ecol. Prog. Ser. 78: 173-187

Ang, P. O. (1992). Cost of reproduction in Fucus distichus. Mar. Ecol. Prog. Ser. 89: 25-35

Ardré, F. (1970). Contribution à l'étude des algues marines du Portugal. I. La flore. Port. Acta Biol. 10: 1-423

Armisén, R., Galatas, F. (1987). Production, properties and uses of agar. FAO Fisheries Technical Paper 288: 1-57

Barilotti, C., Silverthorne, W. (1972). A resource management study of Gelidium robustum. Proc. Int. Seaweed Symp. 7 : $255-261$

Bierzychudeck, P. (1982). The demography of Jack-in-thepulpit, a forest perennial that changes sex. Ecol. Monogr. 52: $335-351$

Bishop, Y M. M., Fienberg, S. E., Holland, P. W. (1975). Discrete multivariate analysis: theory and practice. MIT Press, Cambridge

Caswell, H. (1989). Matrix population models: construction, analysis and interpretation. Sinauer, Sunderland, MA

Chapman, A. R. O. (1984). Reproduction, recruitment and mortality in two species of Laminaria in southeast Nova Scotia. J. exp. mar. Biol. Ecol. 78: 99-110

Chapman, A. R. O. (1986). Age versus stage: an analysis of age- and size-specific mortality and reproduction in a population of Laminaria longicruris Pyl. J. exp. mar. Biol. Ecol. 97: 113-122
Chapman, A. R. O., Craigie, J. S. (1977). Seasonal growth in Laminaria longicruris: relations with dissolved inorganic nutrients and internal reserves of nitrogen. Mar Biol. 40: $197-205$

Chapman, A. R. O., Craigie, J. S. (1978). Seasonal growth in Laminaria longicruris: relations with reserve carbohydrate storage and production. Mar. Biol. 46: 209-213

Chopin, T., Pringle, J. D., Semple, R. E. (1992). Impact of harvesting on frond density and biomass of Irish moss (Chondrus crispus Stackhouse) beds in the southern Gulf of St. Lawrence. Can. J. Fish. Aquat. Sci. 49: 349-357

Dayton, P. K., Curne, V., Gerrodette, B., Keller, B., Roshental, R, Ven Tresca, D. (1984). Patch dynamics and stability of some California kelp communities. Ecol. Monogr. 54: 253-289

De Wreede, R. E. (1984). Growth and age class distribution of Pterygophora californica (Phaeophyta). Mar. Ecol. Prog. Ser. 19: 93-100

Dean, T. A., Thies, K., Lagos, S. L. (1989). Survival of juvenile giant kelp: the effects of demographic factors, competitors, and grazers. Ecology 70: 483-495

Dion, P., Délépine, R. (1983). Experimental ecology of Gigartina stellata (Rhodophyta) at Roscoff, France, using an in situ culture method. Bot. Mar. 26: 201-211

Dixon, P. S. (1958). The structure and development of the thallus in the British species of Gelidium and Pterocladia. Ann. Bot. 22: 353-368

Dixon, P. S. (1959). The structure and development of the reproductive organs and carposporophyte in two British species of Gelidium and Pterocladia. Ann. Bot. 22: 397-407

Dixon, P. S. (1973). Biology of the Rhodophyta. Oliver \& Boyd, Edinburgh

Fan, K. C. (1961). Morphological studies of the Gelidiales. Univ. Calif. Publ. Bot. 32: 315-368

Felicini, G. P. (1970). Richerche sulla rigeneratione in coltura di Pterocladia capillacea. 2. Influenza dell'intensitá luminosa sulla morfologia del tallo. G. bot. it. 104: 35-47

Felicini, G. P., Arrigoni, O. (1967). Ricerche sulla rigeneratione in coltura di Pterocladia capillacea. G. bot. it. 101: $123-129$

Fienberg, S. E. (1979). The analysis of cross-classified categorical data. MIT Press, Cambridge

Gorostiaga, J. M. (1990). Aspectos demográficos del alga roja Gelidium sesquipedale (Clemente) Thuret. Discusión sobre su adequada gestión como recurso explotable. Ph.D. dissertation, Universidad del Pais Vasco, Bilbao

Groenendael, J. M. van, Slim, P. (1988). The contrasting dynamics of two populations of Plantago lanceolata, classified by age and size. J. Ecol 76: 585-599

Guzmán del Proó, S. A., de la Campa de Guzmán, S. (1979). Gelidium robustum (Florideophyceae), an agarophyte of Baja California, Mexico. Proc. int. Seaweed Symp. 9 303-308

Harper, J. L. (1977). Population biology of plants. Academic Press, London

Huenneke, L. F, Marks, P. L. (1987). Stem dynamics of the shrub Alnus incana spp. rugosa: transition matrix models Ecology 68: 1234-1242

Johnstone, G. R., Feeney, F. L. (1944). Periodicity of Gelidium cartilagineum, a perenial red alga. Am. J. Bot. 31: 25-29

Juanes, J. A., Borja, A. (1991). Biological criteria for the exploitation of the commercially important species of Gelidium in Spain. Hydrobiologia 221: 45-54

Kain, J. M. (1987). Patterns of relative growth in Nereocystis luetkeana (Phaeophyta). J. Phycol. 23: 181-187

Klein, B. (1987). The phenology of Dumontia contorta (Rhodophyta) studied by following individual plants in situ at 
Roscoff, Northern Brittany. Bot. Mar. 30: 187-194

Kylin, H. (1956). Die Gattungen der Rhodophyceen. Gleerup, Lund

L'Hardy-Halos, M.-Th. (1971). Recherches sur les Céramiacées (Rhodophycées, Céramiales) et leur morphogénèse. III. Observations et recherches expérimentales sur la polarité cellulaire et la hiérarchisation des éléments de la fronde. Rev. Gén. Bot. 78: 407-491

Lüning, K. (1990). Seaweeds. Their environment, biogeography, and ecophysiology. John Wiley and Sons, Inc., New York

McLachlan, J. (1985). Macroalgae (seaweeds): Industrial resources and their utilization. Plant Soil 89: 137-157

Meagher, T. R., Antonovics, J. (1982). The population biology of Chamaelirium luteum, a dioecious member of the lily family: life history studies. Ecology 63: 1690-1700

Moloney, K. A. (1986). A generalized algorithm for determining category size. Oecologia 69: 176-180

Reed, D. (1990). The effects of variable settlement and early competition on patterns of kelp recruitment. Ecology 7: $776-787$

Reguera, B., Salinas, J. M., Gancedo, R. (1978). Biometria en Gelidium sesquipedale (Rhodophyta). Segunda Parte. Bol. lnst. esp. Oceanogr. 4: 101-138

Rodriguez, D., Santelices, B. (1987). Patterns of apical structure in the genera Gelidium and Pterocladia (Gelidiaceae, Rhodophyta). Hydrobiologia 151/152: 199-203

Salinas, J. M., Reguera, B., Gancedo, R. (1976). Biometria en Gelidium sesquipedale (Rhodophyta). Primera Parte. Bol. Inst. esp. Oceanogr. 226: 1-70

Santelices, B. (1978). Multiple interaction of factors in the distribution of some Hawaiian Gelidiales (Rhodophyta) Pacif. Sci. 32: 119-147

Santelices, B. (1988). Synopsis of biological data on the seaweed genera Gelidium and Pterocladia (Rhodophyta). FAO Fisheries Synopsis 145

This article was submitted to the editor
Santos, R. (1993a). Population ecology of the commercial seaweed, Gelidium sesquipedale: biological input for resource management. Ph.D. dissertation, Dalhousie University

Santos, R. (1993b). A multivariate study of biotic and abiotic relationships in a subtidal algal stand. Mar Ecol. Prog. Ser. 94: 181-190

Santos, R. (1993c). Plucking or cutting Gelidium sesquipedale? A demographic simulation of harvest impact using a population projection matrix model. Hydrobiologia 260/261. 269-276

Santos, R., Duarte, P. (1991). Marine plant harvest in Portugal. J. appl. Phycol. 3: 11-18

Schiel, D. R. (1985). Growth, survival and reproduction of two species of marine algae at different densities in natural stands. J. Ecol. 73: 199-217

Seoane-Camba, J. (1966). Algunos datos de interés en la recolección de Gelidium sesquipedale. Publ. técn. J. Est. Pesca 5: $437-455$

Seoane-Camba, J. (1969). Crecimiento, producción y desprendimiento de biomassa en Gelidium sesquipedale (Clem.) Thuret. Proc. int. Seaweed Symp. 6: 365-374

Sharp, G. J., Tremblay, D. M. (1985). A tagging technique for small macrophytes. Bot. Mar. 28: 549-551

Silverthorne, W. (1977). Optimal production from a seaweed resource. Bot. Mar. 20: 75-98

Stewart, J. G. (1983). Vegetative growth rates of Pterocladia capillacea (Gelidiaceae, Rhodophyta). Bot. Mar. 26: 85-94

Vandermeer, J. (1978). Choosing category size in a stage projection matrix. Oecologia 32: 79-84

Weiner, J., Thomas, S. C. (1986). Size variability and competition in plant monocultures. Oikos 47: 211-222

White, J. (1979). The plant as a metapopulation. A. Rev. Ecol. Syst. 10: 109-145

Wilkinson, L. (1989). SYSTAT the system for statistics. SYSTAT, Inc., Evanston, IL

Manuscript first received: November 26, 1993

Revised version accepted: February 3, 1994 